\title{
Plotinus's conception of unity and multiplicity as the root to the medieval distinction between lux and lumen
}

\author{
Yael Raizman-Kedar \\ Department of Philosophy, University of Haifa, Haifa 31905, Israel
}

Received 30 June 2005; received in revised form 12 November 2005

\begin{abstract}
Plotinus resolved the paradox of the immanent transcendence, characterizing the relation between the One and the universe, through his theory of the two energeiai. According to this doctrine, all existents have an internal activity and an external activity: the internal activity comprises the true essence and substance of each being; the external activity is emitted outwards as its image. The source of the emission is thus present in the lower layer of being by virtue of its manifold images. The prominence given to light in elucidating this solution led to a distinction between two types of lights: an original light, corresponding to the internal energeia of every existent, and a secondary light, which is the outflow and image of the first light, existing outside of the luminous body.

This paper demonstrates the striking similarity between these two Plotinian lights and the concepts of lux and lumen developed by two thirteenth-century philosophers: Robert Grosseteste and Albertus Magnus. Moreover, the paper contends that the purpose of these two medieval concepts of light was identical to what Plotinus had in mind when he first made the distinction: to account for the relation between the one and the many.

(C) 2006 Elsevier Ltd. All rights reserved.
\end{abstract}

Keywords: Plotinus; Albertus Magnus; Robert Grosseteste; Light; Lux; Lumen

E-mail address: yraizman@study.haifa.ac.il (Y. Raizman-Kedar). 


\section{Introduction}

From the second half of the twelfth century through the time of Kepler (1571-1630) and Descartes (1596-1650), light was referred to by two distinct terms: lux and lumen. This distinction was used in various contexts, whether scientific, philosophical or theological. The most crucial definition of the two terms as distinct was likely that of the Muslim philosopher and physician Ibn Sina (980-1037). In his commentary on Aristotle's De anima, ${ }^{1}$ he wrote:

There are these three intentions... of which one is the quality which sight perceives in the sun and in fire... the second is that which shines back due to these [sun or fire], that is, the splendour which is seen to fall on bodies and white or black or green is revealed in them... If this takes place in one of the phenomena that have light inherently, it will be called lux and its offshoot will be called lumen. ${ }^{2}$

This definition became standard terminology in medieval literature, pervading all areas and disciplines.

This paper is concerned with the philosophical motivation for viewing light as a concept split in two. It claims that the distinction between two kinds of lights had long preceded the actual coining of distinct terms for these types. It further demonstrates that the origin for this need can be found within the metaphysical system developed by Plotinus (204270). Plotinus's assertion of two basic metaphysical poles of existence-unity and multiplicity - will be shown to stand at the heart of the matter.

Among other things, the position taken here implies that light was not divided into lux and lumen in order to draw a line between the physical and geometrical, or between the sensible and spiritual aspects of light, nor was the division intended to reconcile the Platonic and Aristotelian explanations of light. ${ }^{3}$ Indeed, once formulated the distinction was used for various purposes, among them those mentioned above. ${ }^{4}$ Nevertheless, I contend that the origin of this clear cut division can be found exclusively within the philosophy of Plotinus, as expressed in his Enneads. The Aristotelian influences leading to this divisionand surely there were such influences 5 - are already present in the Enneads, and therefore may not be attributed to the influence of the new twelfth-century translations.

In order to establish the claim that the distinction between two types of light originated in the work of Plotinus, I first examine the notion of the Plotinian One and its relation to multiplicity. Next, I demonstrate the pivotal role of light as the most appropriate analogy for these relations. The split of light in two is shown to be the outcome of the role of light as the leading metaphor elucidating the complicated relations of proximity and distance,

\footnotetext{
1 Translated into Latin in the second half of the twelfth century by Avendauth and Dominicus Gundissalinus.

2 Avicenna, Liber de anima III, c.1. Quoted and translated in Gilson (2000), pp. 25-26. For a detailed analysis of Ibn-Sina's definitions see Hasse (2000), pp. 107-123. Hasse stresses (p. 113) that Ibn-Sina did not accept the Aristotelian doctrine of light. He concludes (p. 115) that 'There is hardly any Western reader who does not give an Aristotelian or Grossetestian bent to Avicenna's concept of acquired light (lumen)'. Hasse himself thinks such a bent to be a mistake.

${ }^{3}$ For such accounts, see Ronchi (1970), pp. 61-62; Jay (1993), p. 106; Zajonc (1993), p. 98.

${ }^{4}$ See Smith (2000), pp. 315-336.

5 One example of Aristotelian influence is the use of the Aristotelian term energeia or 'activity'. See Gerson (1997), p. 295, and Bradshaw (2004), pp. 91-92. Another Aristotelian principle employed by Plotinus is that everything complete or perfect tends to reproduce itself. See Bussanich (1996), p. 47.
} 
identity and difference between the One and what ensues from it. In the following, I exhibit a close correspondence between the medieval use of lux and lumen as two distinct terms for light on the one hand, and the Plotinian notion of 'light from light' on the other. The relation between lux and lumen, like the relation between the generator and its images, are shown to resemble those existing between a unified principle and its particular instances on every level of the Plotinian universe.

Establishing the above correspondence is based on the writings of two thirteenth-century scholars: Robert Grosseteste (1168-1253) and Albertus Magnus (1193/1200-1280). Both devoted extensive discussions to light, and both lived during the decisive period when Greek writings were rediscovered and translated into Latin, as were the commentaries and innovations made by Arab scholarship. Hence, the terms as used by these two scholars had a definitive impact over the next three hundred years.

The question of the precise textual transmission of the Plotinian ideas in the Middle Ages is only slightly dealt with here, since the paper proposes a philosophical rather than historical analysis. For the argument to work, all that needs to be shown is that both Grosseteste and Albertus had access to some version or adaptation of Plotinian ideas.

The enquiry of exactly when and where these two distinct terms were coined is important and deserving of study, yet it is beyond the scope of this paper. ${ }^{6}$ The proposal of this paper is to point out the striking similarity between the Plotinian handling of unity and multiplicity through the division of light on the one hand, and the high medieval tendency to split light on the other.

\section{Plotinus on unity and multiplicity}

The problem of creating multiplicity from unity is present throughout the Enneads, and seems to be of major concern for Plotinus. He asks:

How from the One, if it is such as we say it is, anything else, whether a multiplicity or a dyad or a number, came into existence, and why it did not on the contrary remain by itself, but such a great multiplicity flowed from it as that which is seen to exist in beings, but which we think is right to refer back to the One. ${ }^{7}$

Plotinus's answer to this question is formulated primarily in terms of a necessary begetting, overflowing, emanation or proceeding. ${ }^{8}$ But the important point in this process, by which the One transcends its unity to become particularized, is that it does so without its unity being lessened, without its transcendence hampered and without being changed

\footnotetext{
${ }^{6}$ Ibn Sina used two distinct Arab terms for light—nur and daw. Nur was translated as lux; daw as lumen. Ibn AlHaytham (965-1040) used only daw, although as Sabra (1989, pp. 21-23), notes, he did distinguish between substantial and accidental lights.

7 Enneads 5.1.6, Vol.5, p. 29. All the references to the Enneads are-unless stated otherwise-to Armstrong's translation (Plotinus, 1966-1988).

${ }^{8}$ The accuracy of the metaphor of emanation in describing the peculiar relationship between the One and the intellect had been doubted by prominent researchers such as Arthur Armstrong and Lloyd Gerson. Armstrong for one writes that emanation in Plotinus 'has not got any precise philosophical meaning' and that Plotinus in this case 'conceals a confusion of thought under a cloud of metaphors' (Armstrong, 1937, p. 61). See also Gerson (1993). However, in this paper I am concerned not with the adequacy of the metaphor, but rather with its influence upon the understanding of light. Hence, the determination of the exact nature of the correspondence between the metaphor and what it is supposed to describe does not seem to be vital for this study.
} 
or moved. Whatever comes into being from it 'does not come into being from it, but from it as it abides unchanged'. ${ }^{9}$ The perfect and real is eternal and not liable to change. The One has to be transcendental because, according to Plato's doctrine as presented in the Republic, the measure which produces essence - in other words the One - cannot be itself an essence. ${ }^{10}$ That which gives form cannot itself be a form. The formlessness of the One attests that it is not limited in the way that being or essence is limited. ${ }^{11}$ If it were limited, this would not only be a sign of a limited perfection, but would also render it a particular being among other particular beings. ${ }^{12}$ Further, the One can have nothing in common with the things that come after it; the common element would otherwise be anterior to it. ${ }^{13}$ The One appears accordingly in Plotinus as a non-being, endowing being to all, ${ }^{14}$ and as a formless principle which is the source of forms for the entire universe. ${ }^{15}$

Yet, this 'measure', whose transcendence had to be preserved in order for something to be defined, must also be present in the defined from within. The One is needed here as the principle of unity as a condition of an ordered system, ${ }^{16}$ and in fact, of existence. Unity is the power endowing existence to all beings, giving them their essential nature, their identity and recognizability. ${ }^{17}$ When things stop being one, they disintegrate and cease to exist. This has to do as well with the Plotinian insistence on the continuity of the universe. Such continuity cannot exist if there is no absorption of the lower reality into the higher. Accurately interpreted, the Platonic transcendence fundamentally implies - according to Plotinusimmanence. ${ }^{18}$ In sharp contrast to the Platonic and Gnostic outlooks, Plotinus strives to keep the universe as one. The highest realities are present here and now. ${ }^{19}$ The One is to be defined accordingly as at the same time transcendent and omnipresent:

For there must be something simple before all things, and this must be other before all things which come after it, existing by itself, not mixed with the things which derive from it, and all the same able to be present in a different way to these other things, being really one, and not a different being and then one. ${ }^{20}$

The same problem is repeated in the lower levels of being. How can the separate and independent nature of intelligible reality be present in the sensible world without corruption of its unity and identity? And how can the Soul be 'indivisibly divided' when it comes to be in different bodies? ${ }^{21}$ The solution offered by Plotinus is the universal principle of two energeiai: the one internal to the engendering entity; the other external. According to this principle:

\footnotetext{
9 Enneads, Vol.5, 5.4.2, p. 147.

10 Brehier (1962), p. 135. For the One as 'measure and not measured' see Enneads 5.5.3 and 5.8.18.

11 Bussanich (1996), p. 44.

12 Hager (1993), p. 53.

13 See Roeser (1945), p. 93.

14 Enneads 5.2.1, Vol. 5, p. 59: 'the one is not being, but the generator of being'. See also 6.7.32, 6.8.16 and 6.2.9.

15 Ibid., 6.7.17, Vol. 7, p. 141: 'and the form was in that which was shaped, but the shaper was shapeless'. See also 6.7.28 and 6.7.33.

16 Brehier (1962), p. 136. For the One as imparting unity, see also Enneads 5.3.15, 5.5.3 and 5.6.3.

17 Hager (1993), p. 49.

18 Ibid., p. 59.

19 For this theme see Hadley (1997).

20 Enneads 5.4.1, Vol. 5, p. 141.

21 Ibid., 4.2.1, Vol. 4, pp. 21-23.
} 
All things which exist, as long as they remain in being, necessarily produce from their own substances... a surrounding reality directed to what is outside them, a kind of image of the archetypes from which it was produced... ${ }^{22}$

The higher level of being is thus present in the lower, not as itself, but as an image. The source of these images remains distinct and unchanged. Every entity at each level is now producing, and its product is an extension of its being, yet not identical with it: ${ }^{23}$

In each and every thing there is an activity which belongs to substance and one which goes out from substance; and that which belongs to substance is the active actuality which is each particular thing, and the other activity derives from that first one, and must in everything be a consequence of it, different from the thing itself. ${ }^{24}$

Both the source and the image are denominated as activities or energeiai, ${ }^{25}$ yet the source is called 'active actuality' and identified with substance. The first is the cause, while the second is an effect. They are ordered, with the substance coming first and its outcome second and there is a delicate play of identity and difference between them. David Bradshaw writes that the doctrine of two energeiai is used by Plotinus to achieve exactly this: a balanced emphasis on likeness, distinctness and an ongoing dependence. ${ }^{26}$

The notion of image enables Plotinus to speak of the One, the Intellect or the Soul as being at the same time transcendent and omnipresent. They are omnipresent through their generated images, while as sources, as the thing in itself, they remain aloof. The relation of 'being an image of' is a relation of resemblance. This notion was analyzed by Paul Ricoeur as a concept that 'opposes and unites identity and difference'. ${ }^{27}$ Ricoeur believes that the use of metaphor is the best way to demonstrate and, in fact, create the relation of resemblance. The use of metaphor in solving the problem of the immanent transcendence is therefore not a mere illustration. It is, indeed, the instrument that provides the most direct access to resemblance itself. It is not a description of this notion, but rather its presentation.

Given his mistrust in discursive thinking, ${ }^{28}$ Plotinus recruited several metaphors in order to explain the notion of a unity that manifests its presence within multiplicity

\footnotetext{
22 Ibid., 5.1.6, Vol. 5, p. 31.

23 The relation between a hypostasis and its product is often expressed in Plotinus by the term logos (for example, see 5.1.6). One meaning of logos in Plotinus is the formative force proceeding from a higher principle, expressing that principle in a lower plane of being. Thus, the second, external energeia can be identified with Plotinus's notion of logos (Armstrong, 1967, p. 105). Just the same, Plotinus often suggests that light is a logos and a form-giving principle (see n. 56). In the writings of Augustine (354 430) logos becomes the aspect of the Trinity involved with the incarnation of Jesus, and in the thirteenth century we find that lux and lumen are used in order to illustrate the relations between the members of the Trinity, with lux playing the role of the Father, and lumen the role of the Son. One such example is found in Grosseteste's Hexaëmeron, pa. 8, ch. 3.1; Grosseteste (1996b), p. 224.

24 Enneads 5.4.2, Vol. 5, p. 147.

25 Aristotle thought of energeia as actuality or an exercise of a capacity. Plotinus envisioned the internal energeia also as intrinsically productive. For the meaning of this term in both Aristotle and Plotinus, see Bradshaw (2004).

26 Bradshaw (2004), p. 80

27 Ricoeur (1977), p. 196.

${ }^{28}$ For this theme see Bussinach (1996), p. 39, and Brehier (1962), p. 30: 'the image in Plotinus is not an external ornament but an integral element... he aspires... to give utterance to realities which language is powerless to convey. The alternative left is to suggest them through analogy'. See also Rappe (1995), p. 156: 'Plotinus thinks that language fails as a vehicle for conveying metaphysical truth since words necessarily refer to entities standing outside of the linguistic system, whereas truth is both self-certifying and self-revealing'.
} 
through its generated images. But which metaphor would be the most suitable for this task?

\section{Light is the answer}

Before approaching these metaphors, I first examine the structure of the relation that these figures of speech are intended to explicate. John Fielder suggests four such characteristics for the relation between an archetype and its images: difference; similarity, that is, resemblance; inferiority and dependence of the image on the archetype. ${ }^{29}$ Based on this list and on Frederic Schroeder's suggestions, ${ }^{30}$ I propose the following traits: (1) the source must logically and ontologically precede its offspring; (2) the existence of progeny must be totally dependent on the source, and when the source ceases to exist, the offspring must immediately disappear as well; (3) the offspring must maintain an immediate, dynamic and continuous relationship with its source in order to preserve its existence; (4) the copy must resemble the source in some way; (5) and yet it has to be different from it; if it would spread itself, the source would be diminished; (6) the source must be wholly present in a plurality of different offsprings in different spatial locations without being divided among them.

Plotinus uses a number of explicative metaphors for the paradox: fire producing heat and snow generating cold; perfumed objects spreading their smell; ${ }^{31}$ a plant growing from a seed or from a root; a spring and the rivers that rise from it; ${ }^{32}$ a model and its portrait; a mirror image ${ }^{33}$ and light emanating from the sun or any other luminous body. ${ }^{34}$ As Fielder notes, each of these metaphors suggests a different sense of generation. The mature plant comes into being only through the destruction of the seed, whereas the sun continues to exist despite its production of light. Perfumes are weakened or diluted by the air as they are diffused, but a mature plant and the mirror image are not similarly diminished copies. ${ }^{35}$ The relation between a portrait and a person portrayed is disqualified as an appropriate metaphor based upon conditions (2), (3) and (6) above: the portrait remains viable even in the absence of the origin, and nothing of the portrayed person remains within its image. Similarly, the fire and its heat are not suitable as illustrations for the One and its images based upon conditions (3) and (4): some warmth remains when fire is put out. Furthermore, warmth cannot be called the image of fire, since it does not resemble it. ${ }^{36}$ Hence, I agree with Fielder, Schroeder and Werner Beierwaltes ${ }^{37}$ who claimed that light is the most adequate of all metaphors used by Plotinus to clarify the relation between a source and its copy, and for any kind of generation of one level of being from another. It is the most suitable paradigm for several reasons, but most of all since it is the only sensible analogy that has something in common with what it accounts for: incorporeality. The incorporeality of the One is a prominent element in Plotinus's explanation of its ability to be

\footnotetext{
${ }^{29}$ See Fielder (1976), pp. 103-104; Schroeder (1996), p. 338.

30 Schroeder (1992), p. 24.

31 Enneads 5.1.6, Vol. 5, p. 31 and 5.4.1, Vol. 5, p. 143.

32 Ibid., 3.8.10, Vol. 3, p. 395.

33 Ibid., 6.4.10, Vol. 6, p. 305.

34 Ibid., 5.3.12, Vol. 5, p. 117.

35 Fielder (1976), pp. 106-107.

36 Enneads 6.4.10, Vol. 6, p. 305.

37 See Fielder (1976), pp. 107-108; Schroeder (1992), pp. 32-35; Beierwaltes (1961).
} 
omnipresent without being divided. In fact, light is the only analogy that does not violate requirement (6). When Plotinus inquires 'how it is the same which is over all', ${ }^{38}$ he immediately presents a lengthy demonstration of the incorporeality of the source of light, which although present within a luminous body, is not in fact a part of its mass. It is, rather, a power, residing within that body:

For it is not in that it is body that it has the light, but in that it is luminous body, by another power which is not bodily. ${ }^{39}$

Once defined as a power that cannot be located spatially, light can be said to reside in many locations without being divided: 'that which belongs to no body... cannot be divided into parts' for 'how would you divide that which has no magnitude? ${ }^{40}$ Thus light is 'equally diffused within and throughout the entire sphere... simultaneously present at each and every point in the sphere'. ${ }^{41}$

Plotinus stresses another feature which renders light the most suitable metaphor to explicate the connection between the One and being: its necessary dependence on its source:

Just as the image of something, like the weaker light, if cut off from that from which it is, would no longer exist, and in general one cannot cut off and make exist [separately] anything at all which derives its existence from something else and is its image. $^{42}$

Hence, light remains as the only suitable metaphor for the analyzed relations. This comes as no surprise to either Schroeder or Beierwaltes, for according to them the image of light in Plotinus is much more than an illustration. It becomes a mode that actually casts and directs the terms of analysis. They believe that light in Plotinus is not another metaphor: the One is light proprio sensu, and the procession from it is the procession of light from a source. ${ }^{43}$ Even if we choose not to follow this line of thought to its limits, ${ }^{44}$ we are still compelled to acknowledge the centrality and uniqueness of the function of light in explicating the relation between the One and what proceeds from it.

\section{One light is not enough}

In this section I put forward the following argument: Plotinus's solution to the paradox of the immanent transcendence, in terms of two energeiai combined with light as a leading metaphor, entails a split of light in two, each light corresponding to a different energeia or activity.

\footnotetext{
${ }_{38}$ Enneads 6.4.7, Vol. 6, p. 293.

${ }^{39}$ Ibid., p. 295.

${ }^{40}$ Ibid., 6.4.8, p. 299.

${ }^{41}$ Enneads 6.4.7; Plotinus (1991), p. 446. Due to its clarity, I favored MacKenna's translation here.

42 Enneads 6.4.9, Vol. 6, p. 303.

${ }^{43}$ See Beierwaltes (1961); Schroeder (1996), pp. 341-344. Rein Ferwerda (1965) represents the alternative view, according to which symbols in the Enneads only redescribe the doctrinal content, and do not contribute to meaning. That is, light in his view does not designate the true nature of the three hypostases.

${ }^{44}$ Not withstanding my conviction that the selection and use of analogies in Plotinus is not ornamental, but rather inherent to his philosophical outlook, my argument does not depend on accepting this position and can hold even if light is viewed as an illustrative metaphor and nothing else.
} 
Let us examine a few passages in which light is employed in order to clarify the relation of generation and image between the different levels of being:

But the activity within the luminous body, which is like its life, is greater and is a kind of source and origin of its [outward] activity; that which is outside the limits of the body, an image of that within, is a second activity which is not separated from the first. ${ }^{45}$

This quotation clearly shows how light is considered a particular instance for the general principle of an active, internal actuality generating an outward actuality - the external actuality being different from the first and weaker, yet similar and connected: it is its image. Plotinus writes of two lights again in 2.1.7:

But by fire he [Plato] does not mean either of the other kinds of fire but the light which he says is other than flame, and only gently warm. This light is a body, but another light shines from it which has the same name, which we teach is incorporeal. This is given from the first light, shining out from it as its flower and splendour; that first light is the truly bright and clear body. ${ }^{46}$

Here the difference between the two lights seems to be the difference between the corporeal and spiritual lights. However, as indicated above, this is not the case. According to Plotinus, the light inside the luminous source resides in a body, but is not itself material: 'but one must consider light as altogether incorporeal, even if it belongs to a body'. ${ }^{47}$ It seems to me that the difference here is that between light as substance and light as a quality or an accident. The substantial light is the 'true' light, while the accidental quality is its image. The image depends upon the source in the same way as a quality depends on a substance. When the substance ceases to exist, its qualities disappear with it. Plotinus specifically says that:

The light in bodies of this kind, bodies, that is, which are primarily and originally of this kind, is altogether substance, corresponding to the form of the primarily luminous body. ${ }^{48}$

From the split of light into substantial and accidental, it follows necessarily that of the two lights, only the second - that is, the splendor - is accessible to the sense of sight. Plotinus held to the principle according to 'that which is known by our sense-perception is an image of the thing, and sense-perception does not apprehend the thing itself; for that remains outside'. ${ }^{49}$ However, as far as sunlight is concerned, Plotinus seems to think that we can sometimes see it directly, before it has illuminated the intermediate air:

For when the light of the sun approaches... we often perceive it when it is elsewhere, before it comes near our eyes... and when the light with which our sight must connect has not arrived. ${ }^{50}$

\footnotetext{
45 Enneads 4.5.7, Vol. 4, pp. 305-307.

46 Ibid., 2.1.7., Vol.2, pp. 29-31.

47 Ibid.

48 Ibid., 4.5.7, Vol. 4, p. 309.

49 Ibid., 5.5.1, Vol. 5, p. 157 and 2.6.1. See also Emilsson (1988), p. 52.

50 Enneads 4.5.4, Vol. 4, p. 297.
} 
Yet this is an exception, and normally that 'light with which our sight must connect' is the second, not the first light. In discussing the relation between the One and the intellect, Plotinus again refers to the two lights. The intellect in relation to the One

Is like a light dispersed far and wide from some one thing translucent in itself; what is dispersed is image, but that from which it comes is truth; though certainly the dispersed image, Intellect, is not of alien form. ${ }^{51}$

This is a straightforward indication for the claim that the split of light accounts for the relations between unity and plurality. The Intellect is the first dyad according to Plotinus, for it involves the duality of a thought and its object. Here it is compared with the second light, the dispersed one. The scattered light is thus born in plurality. The point stressed in this last citation, is that although the second light is an image of the first, it nevertheless shares similarity of genre with it: they are of the same kind. The distinction between light and its source can thus account both for the continuity of the various levels - as the two lights are of the same kind and continuously connected - and for their otherness. Otherness in Plotinus consists in the notion of image as less than and dependent upon its prior. ${ }^{52}$ And this is the essence of their difference. Plotinus further states that the Intellect is separated from the One 'only by otherness'. 53

In his paper on light in Plotinus and Aquinas, Kevin Corrigan attempts to define these two lights discussed by Plotinus. In Corrigan's view, the light inside a luminous body is an incorporeal energeia, a dynamic, substantial activity, while the light in the diaphanous is a quality of a substrate, an accident to the substance of the object. This external activity is the visible, perceptible light. ${ }^{54}$ Accordingly, he set the first, 'internal' light as the substantial meaning of light, which is intelligible. The internal, intelligible light becomes thus a source both of being and of understanding of the external light, that is, of the 'physical', corporeal light. ${ }^{55}$ I find this interpretation difficult to accept, despite its appealing nature as far as the treatment of metaphor is concerned. My difficulty lies in the fact that in Plotinus both lights are incorporeal, and the second light is specifically defined as a form, and, as has just been indicated, equated with the Intellect. ${ }^{56}$ Moreover, light in Plotinus is used to define the exact nature of the immaterial, and only through its attributes can he begin to formulate a positive account of relation between the forms and their sensible participants. In my view, the difference between the two kinds of light is not the difference between the spiritual and the corporeal, but rather between the principles of unity and of multiplicity. The second light in Plotinus is the Intellect with its manifold forms, not the material world. The two lights are referred to again when the relation of the universal Soul to the particular souls is explained, and here too, only incorporeal entities are at stake. It is true that at a certain level the tension between unity and multiplicity becomes the tension between the one intelligible form and the many material entities defined by it. Yet, if we concentrate on

\footnotetext{
51 Ibid., 6.8.18, Vol. 7, p. 289.

52 Gurtler (1992), p. 456.

53 Enneads 5.6.1, Vol. 5, p. 33. See also Rist (1967), pp. 29-30.

54 Corrigan (1993), p. 192.

55 Ibid., p. 193.

${ }^{56}$ For example, in Enneads 1.6.3, the light present in the lower level, that of corporeal particular entities, is explicitly said to be unembodied: 'The simple beauty of color comes about by shape and the mastery of the darkness in matter by the presence of light which is incorporeal and formative power and form' (Vol. 1, p. 241); and in 2.4.5, Plotinus writes: 'the light [in each thing] is the rational forming principle' (Vol. 4, p. 115).
} 
this level of being alone, we might loose sight of the general problem, repeated at all levels of existence, that of the relation between the one and the many, a problem of concern for Plotinus throughout.

It is possible, however, to view the split as that between the immanent forms, which Plotinus associates with accidents, and the transcendent forms, which he associates with substance. ${ }^{57}$ The transcendent forms are the first kind of light, while the immanent ones are the second.

Plotinus refers, therefore, to two lights: a first and a second. The first light is internal to a luminous body; it is an inner activity, which is also the true thing or the 'thing itself', or maybe even the (spiritual) substance of such a body; it is unmoved and unchanged, yet it is productive. Ontologically, it precedes the second and it is the source and origin of this other light, which is its image. The second light is placed outside; it is diffused afar and travels in space. This last attribute enables it to reach our eyes and be seen, a quality lacking in the first light. In the following I show that the notions of lux and lumen in the writings of Grosseteste and Albertus are used and defined by these very same qualifications. Yet before that a comment is in place concerning the way Grosseteste and Albertus became familiar with the Plotinian ideas.

\section{The two lights transmitted}

I draw attention to two routes through which Grosseteste and Albertus could have learnt the Plotinian idea of two lights. Indeed, it seems likely that these two routes had a parallel impact upon the two writers. ${ }^{58}$ One path of influence runs through Ibn Sina, whose famous definitions for lux and lumen have been quoted above. He had at his disposal the Arabic Plotinian texts: the so called Theology of Aristotle, the Letter on divine science and the fragments attributed to the Greek sage (Dicta sapientis Graecis). These were not straight forward translations of the Enneads, but rather a translation-cum-paraphrase, belonging to the body of translations and adaptations made by al-Kindi's (d. 866) circle in ninth century Baghdad. ${ }^{59}$ Al-Kindi's translations were, in turn, extracts from an earlier Arabic paraphrase (now lost) of Plotinus, which itself 'derives ultimately from the Greek of Plotinus' Enneads IV-VI much as we have it today' ${ }^{60}$ Both the theory of the two energeiai $^{61}$ and the notion of two lights are clearly present in these texts. One example is quoted here, yet more can be found:

The action of the sun - that is, light - is life of the pure, transparent body, and is the source and beginning of light. The light on the outer surface of the pure body is but a reflection of the inner light. ${ }^{62}$

\footnotetext{
${ }_{57}$ See Gurtler (1992), p. 456.

58 There are a few other possible paths. For example, Hasse (2000), p. 115, mentions the theory of the tria necessaria, transmitted through Calcidius (ca. fourth century), Macrobius (ca. 430) and William of Conches (1080-1154), as a possible source of the dual terminology for light. Another source could be al-Kindi.

59 Adamson (2000), p. 8.

60 Zimmermann (1986), p. 113.

61 Epistola de scientia divina 173-175. see Plotinus. (1959), p. 337.

62 Dicta sapientis graeci VI 2-3 and I 17-19. See Plotinus. (1959), p. 165 and 367 respectively.
} 
The other path runs through the writings of Pseudo-Dionysius the Aeropagite (ca. 500), which were translated from the Greek in the ninth century by John Scotus Eurigena (810877), and again in the thirteenth century by Grosseteste. In On the divine names Dionysius refers explicitly to the two lights:

From the Good comes the light which is an image of Goodness; wherefore the Good is described by the name of 'Light', being the archetype thereof which is revealed in that image. ${ }^{63}$

This notion is wrapped in a language of emanation, presenting the Good as pouring itself forth while remaining undiminished, unmingled, unified and complete in its distinction. ${ }^{64}$ Interesting to note is that both Eurigena and Grosseteste translated this passage using lumen for the light which is from the Good, and lux for the light as a name of the Good (note the capital 'L'). Dionysius was also a major channel through which the doctrine of two energeai had come to the medieval Latins. This principle, found in the forth chapter of On the divine names, was expressed by Dionysius as bonum est diffusivum sui, and was taken up from there by various thinkers, such as Bonaventure (1221-1274) and Thomas Aquinas (1225/7-1274) to be used in accounts of creation.

\section{Two medieval lights}

Notwithstanding the substantial differences between their uses of the term lux, both Grosseteste and Albertus define lux as the first form and as the form of the luminaries. In Grosseteste, lux is the first corporeal form: 'the first corporeal form which some call corporeity is in my opinion lux'; 'thus lux, which is the first form created in first matter' ${ }^{65}$ As such it is present everywhere in the material world as a principle of extension and energy. ${ }^{66}$ Grosseteste stresses that the firmament - the first created body —is made from lux: both the matter and form of the firmament is the lux prima, and the sun and the other luminaries were made from the firmament, that is, from the primordial lux. ${ }^{67}$ In Grosseteste's view, the bodies of the luminaries and their $l u x$ are of 'one and the same nature and one and the same creation'. ${ }^{68}$ Hence, $l u x$ is not only the form of the luminaries, it is also their matter. This position is consistent with Grosseteste's insistence on the materiality of light.

In the writings of Albertus, lux is defined as the form of a luminous body:

The luminary is a body, which holds in itself $l u x$ as a form. . lux is called the form of lumen in luminaries or in where there is a first source of lumen ${ }^{69}$

However, it is not defined as its substantial form. A substantial form cannot be active, whereas according to Albertus $l u x$ is active, moving towards all forms and instilling them with power. Due to this delivering function, lux can no longer be considered a substantial form, nor an accidental form:

\footnotetext{
${ }^{63}$ On the divine names, 4.4; Dionysius the Areopagite (1951), p. 91.

${ }^{64}$ See, for example, ibid., 2.11, pp. 78-81.

65 On light; Grosseteste (1996a), p. 765.

66 McEvoy (1982), p. 283.

67 On the six days of creation, pa. 5, ch. 4.1; Grosseteste (1996b), p. 161.

68 Ibid., ch. 5.1, p. 162.

69 De anima, lib. 2, tr. 3, cap. 8; Albertus Magnus (1968), p. 110: 63-69.
} 
That which moves towards all the forms of generation and corruption, whether substantial or accidental, is not one with them: that which is moving is not the movement. ${ }^{70}$

The description of $l u x$ as in motion marks a difference from the first Plotinian light, which was characterized as unchanging and unmoved. Yet the complete otherness of lux is preserved. Thus, lux is a special form, which cannot be treated according to the categories of the 'regular' forms. For both authors then, lux enjoys an ontological priority: it is the first created form and identified as the form of a source of light. These characteristics render it similar to Plotinus's first light.

In relation to lumen, lux is explicitly said to be its ontological precedent, as it is its source and origin. Lux is defined by both Grosseteste and Albertus as begetting or transmitting by essence. Grosseteste writes that 'every lux has by nature and essence its splendor that it begets'; ${ }^{71}$ and Albertus states that

It is not the first agent, unless by that which transmits by essence, as lux shines by its essence: and which transmits by essence any action, and does so always and incessantly. $^{72}$

Lumen, in turn, is presented as the outcome of this necessary begetting. It is thus the offspring, copy or image of lux. Grosseteste states that 'one point of lux can fill a whole hemisphere with lumen', ${ }^{73}$ and in another place he refers to the sun, which hides the stars and the moon because 'it does not allow at the same time with her the species of another's lux ${ }^{\prime} .{ }^{74}$ I do not wish to consider the complicated issue of the exact denotation of the term species in medieval use. Suffice it to say that the term species refers to a likeness emanating from an object, which is a sign and representation of the known thing. ${ }^{75}$

Lux is defined in another way by Albertus as the form of lumen in a body that pours the $\operatorname{lux},{ }^{76}$ that is, the origin of which lumen is the copy. As for the other light, Albertus states that 'lumen is now the received form from that which shines at first', 77 and that which shines at first is, of course, lux. Lumen is then the form lux takes when it is received within the various bodies, including the transparent medium. Hence, in Albertus we find the same denotation of lumen as the species or intentio of lux. ${ }^{78}$

Another common feature of lux mentioned by both authors is that it is locked inside bodies. In Grosseteste lux is always attached to matter as the form of corporeity. For

\footnotetext{
70 Super Dionysium De divinis nominibus, cap. 2; Albertus Magnus (1972), p. 62: 38-41.

71 On the six days of creation, pa. 8, ch. 3.1; Grosseteste (1996b), p. 224.

72 De intellectu, lib. 2, tr. 1, cap. 3; Albertus Magnus (1800-1899), p. 507. Recall Plotinus assertion that 'all things when they came to perfection produce; the One is always perfect and therefore produces everlastingly' (Enneads 5.1.6, Vol. 5, p. 33).

73 On the six days of creation, pa. 2, ch. 10.1; Grosseteste (1996b), p. 97.

74 De operatione solis 26; Grosseteste (1974a), p. 85.

75 From the perspective of this paper it is important to note that according to Roger Bacon's list, synonyms for species are, among others: 'image', 'similitude' and 'intentio'. See Bacon (1983), p. 6. For more on this term see Spruit (1994).

${ }^{76}$ De intellectu, tr. 3, cap. 1; Albertus Magnus (1800-1899), p. 498.

77 Ibid.; Bonin (2001), p. 31, also suggests that lux be considered a source in Albertus, while lumen as its effect in another.

78 The claim that lumen is the species of lux had been made in contemporary literature regarding other medieval authors. See Smith (2000), pp. 325-326; and Lindberg (1986), p. 20.
} 
instance, in his discussion of color, we find lux to be a cause of color only from within the colored body: 'for color is lux embodied in a wet transparent medium'. ${ }^{79}$ It is locked inside such a body and cannot express itself without the assistance of the lumen in the diaphanous. ${ }^{80}$ In Albertus lux never moves in space, and is always placed within its proper matter-the thickened transparency.

And the purer it is, the more remote it is from transparency, that is, as it more resembles a thing of higher nature; and the proper actuality of this is the lux which comes into being in that nature, for it comes into being as often as its parts become clearer and nobler, and therefore all such things shine. ${ }^{81}$

According to Albertus, once a transparency becomes clear and pure enough, it loses its transparent nature and becomes thickened. Things that shine are not transparent, because a transparent object can only receive light, not produce it. Therefore, only a thickened transparency can produce light, and lux can inhere only in such matter, whether in heaven or within our eyes.

The notion of lux as locked inside bodies conforms to another trait of the Plotinian first light: its being internal to a self luminous body. In contrast, for both authors, lumen is always out there in the transparent medium, just like the Plotinian second light, which is 'diffused afar'. ${ }^{82}$ Thus, for Grosseteste, while $l u x$ is the cause of color from within the colored body, lumen is such a cause when it is mixed with a transparent medium (diaphanous). ${ }^{83}$ Albertus believes that 'lumen is an intentio having spiritual being in the transparent medium, ${ }^{84}$ and he repeats his assertion in De meteoris:

Lumen is an intentio of the form of a luminous body, which, having spiritual being, is generated in the transparent medium. ${ }^{85}$

The notion of lux as a substance and lumen as its accidental quality is present only in Grosseteste. In his discussion of the question of the substantiality of light, Grosseteste cites John Damascene (676-754/787), who claimed that lumen is a quality of fire, and that since it is always generated by fire it does not have its own "hypostasis", that is, existence in its own right. ${ }^{86}$ Grosseteste then argues that lux has two senses: (1) a very subtle bodily substance which is by nature self-generative; and (2) an accidental quality that proceeds from the natural generative action of the substance of $l u x .^{87}$ Grosseteste does not state this explicitly, but it seems that to him lux is the active substance, and lumen (according to Damascene's own words) is the accidental quality that proceeds from it. In Albertus's view, as already noted, lux is neither substantial nor accidental. Lumen, however, cannot only be considered an accident, but an

\footnotetext{
${ }^{79}$ On the six days of creation, pa. 2, ch. 10.2; Grosseteste (1996b), p. 99. I favored Gilson's translation here (2000, p. 167) over Martin's ('embodied in a clear liquid').

${ }^{80}$ De operatione solis 6; Grosseteste (1974a), pp. 69-70.

81 Albertus, On sense and sensibles, ch. 12. See Akdogan (1978), p. 173.

82 I note one exception: Albertus thought that in regard to transparent bodies, such as stars, lumen can enter their interior and be gathered within them. See Grant (1994), p. 397.

83 On the rainbow; Grosseteste (1974b), p. 391.

${ }^{84}$ De anima, lib. 2, tr. 3, cap. 12; Albertus Magnus (1968), p. 116: 73-74.

85 Albertus, De meteoris, lib. 2, tr. 2, cap. 6. Quoted and trans. in Gilson (2000), p. 64.

86 On the six days of creation, pa. 2, ch. 10.2; Grosseteste (1996b), p. 98.

87 Ibid.
} 
Accidental accident of a body illuminated from another, as the heat is [in itself] an accident of fire and an accidental accident of the heated body. ${ }^{88}$

The two writers also make the same distinction as made by Plotinus between the two lights in regard to their visibility. According to Plotinus, as well as according to Grosseteste and Albertus, only the second light is accessible to our sense of sight. In the latter's writings lumen is often treated as color, and 'color is with the number of those who are visible according to themselves'. ${ }^{89}$ As mentioned above, Grosseteste believes that since lux is always inside bodies, it cannot reach our eyes. The agent traveling in space approaching our senses is lumen. Color according to Albertus 'has the essence and form of color from lumen'. ${ }^{90}$ Yet Albertus goes even further, stating that:

Lumen is the common nature, that makes the visible visible, and color is seen only because it participates within the flow of lumen..$^{91}$

Moreover, Grosseteste sees lumen not only as color, but as daylight as well, for lux, when it is in the sublunary world, incorporated within the elements, looses its power to affect its surrounding and thus cause visibility. But lumen, when it is in the air, has the greatest powers: the air is 'being lit up only as long as lumen is present, and when lumen is gone-it goes back to darkness'. ${ }^{92}$ Lumen, then, is seen as brightness, shining, or daylight. It often appears accompanied by the noun fulgor, that is, 'shining' or 'brightness'. One such an example appears when Grosseteste explains that the stars are beautiful 'simply because they shine with lumen' (luminis fulgore). ${ }^{93}$ In another place Grosseteste explicitly identifies lumen with the power of being seen: 'the sun is in the view of the seeing eye through the strength of its lumen'. 94

And what about lux? Is it also visible? Clearly not, according to Grosseteste, at least not without the help of its messenger lumen, and only through it. ${ }^{95}$ In Albertus the lux of the sun is endowed with visibility, in a way similar to Plotinus. ${ }^{96}$ However, its visibility is unique: it is not seen in the same way as other things are seen. Albertus crowns lux as 'the perfect visible', ${ }^{97}$ meaning that it is seen directly and not through its encounter with matter or through an intermediate.

As claimed above, the Plotinian invention of the two lights results from the principal function given to light in explicating the relations between unity and multiplicity. Next, I seek to show that lux and lumen are used by Grosseteste and Albertus exactly for the

\footnotetext{
88 Super Dionysium De divinis nominibus, cap. 2. 32; Albertus Magnus (1972), p. 64: 17-26.

89 De anima, lib. 2, tr. 3, cap. 7; Albertus Magnus (1968), p. 108: 22-23.

90 De intellectu, tr. 3, cap.1; Albertus Magnus (1800-1899), p. 488.

91 Ibid., p. 109: 13-14.

92 On the six days of creation, pa. 8, ch. 27.11; Grosseteste (1996b), p. 343.

93 Ibid., pa. 2, ch. 10.4, p. 99.

94 De operatione solis 7; Grosseteste (1974a), p. 71.

95 The situation is different when it comes to the beatific vision. In this kind of vision, according to both authors, we do get to see lux directly. However, this issue will not be developed here due to its extensiveness.

96 He writes: 'our sun, that is, which is seen to us with perceiving through its own being, which is the bright, illuminates as if sharing its intentio, which is lux'. Super Dionysium De divinis nominibus, cap. 4. 9; Albertus Magnus (1972), p. 119: 18-22. Note that lux here is only 'as if' an intentio, and the sun is thus perceived directly, through its own being.

97 'We see everything [visible] to be made from that which is by itself and the perfect visible'. De intellectu, lib. 1, tr. 1, cap. 5; Albertus Magnus (1800-1899), p. 480.
} 
same purpose. For both, lux functions as a principle of unity, whereas lumen represents its multiple fragments or splinters. The fact that both are one and the same entity, namely light, demonstrates the feature of immanence in transcendence so vital to the Plotinian outlook.

As the form of corporeity, lux, according to Grosseteste, is present throughout the material universe and is an inherent part of it. Through its powers of self-generation, it endows matter with the most basic bodily feature: extension. The idea of common corporeity links directly to Ibn Gabirol's (1020/1-1070) notion of common corporeity, which was conceived as the form that all things have in common, the simple that imparts unity to all. ${ }^{98}$ Grosseteste had used an existing notion, but its identification with lux is new and original. ${ }^{99}$ It is $l u x$ then that, according to Grosseteste, assures the unity of the material universe. The concept of $l u x$ defined as the common corporeity abolishes the difference in principle whereby the superlunary universe was thought to be of an essentially different make up than the earth (aether), establishing one physical system out of what for Aristotle had been two separated ones. This unified physical system is based on lux. Grosseteste replaced the differences in kind with a distinction in degree of density, perfection and beauty: the lux of the upper world is more rare, noble and perfect that the lux in the sublunary world, yet they are principally the same. ${ }^{100}$

The unitary role of lux does not end here. In De motu corporali et luce, Grosseteste distinguishes (following Aristotle) between two kinds of motion: local motion (motus localis), which takes place through time, and alteration (alteratio, mutatio), which is immediate. He then poses $l u x$ as responsible for both. When it drags matter with it while generating, it produces local motion. Alteration occurs when lux is cast from within a body out to the diaphanous without being accompanied by matter. It then passes through the diaphanous at once. ${ }^{101} \operatorname{Lux}$, then, is the generator of motion.

Through its necessary self multiplication, $l u x$ also serves as the principle of connection. Grosseteste adopts the essentials of al-Kindi's claim that everything acts on everything else through the radiation of force or lux. ${ }^{102}$ According to al-Kindi, Lux is the power residing inside natural bodies, and is the source of their multiplication, that is, the source of their ability to affect their surrounding. No causality is possible without lux and therefore no regularity as well. Grosseteste thus deems lux as the principle of unity in the world, not merely because it is everywhere, but because it enables the different, separate, particular objects to be connected, and to be connected in an ordered, regular manner.

Another example of the unitary function of lux can be found in Albertus's theory of the agent intellect. The relation between the corporeal lux and the intentiones of the colors is compared time and again by Albertus with the relation between the universals within the agent intellect and the universals in each particular soul. That comparison is meant to exemplify the way in which the universals are not individuated when grasped by particular intellects. The agent intellect thus is said to be like lux, which, even though it is in many colored bodies, still has a power that remains universal. ${ }^{103}$ The $l u x$ of the sun is something

\footnotetext{
98 Simson (1962), p. 54.

99 McEvoy (1982), p. 161.

100 Ibid., p. 185.

101 De motu corporali et luce; Grosseteste (1912), p. 92.

102 Lindberg (1986), pp. 16-17.

103 De intellectu, lib. 1, tr. I, cap. 7; Albertus Magnus (1800-1899), p. 488.
} 
determinate in bodies, yet its power, which constitutes the domain of the visible, is not individuated. In exactly the same manner the agent intellect, which constitutes the domain of intelligible forms, is not individuated. ${ }^{104}$ In Albertus, the agent intellect as lux stands out against the plurality of the specific, determinate forms. Albertus states that the agent intellect is similar to lux because both are 'first beings'. He poses the principle that

In the whole world in which some deliver and some are delivered, there is necessarily one first being, which is so great an agent. ${ }^{105}$

The first agent of the whole physical universe is the lux of the sun. Albertus then presents another principle: the human soul is an echo or image of the form of the world. It is similar to the whole universe because its multitude of intellectual beings requires a first agent. This first agent resembles lux, because like $l u x$ it is universal, and like lux it flows and delivers the forms. ${ }^{106}$ However, these forms themselves are not lux; they are lumen: 'form, since it makes a thing knowable, is a sort of lumen'; ${ }^{107}$ and 'these lumina are the forms of the world'. ${ }^{108}$ $\operatorname{Lux}$, then, is the first universal form and the source of all the forms in the universe, and the lumina are the specific forms issued from it: 'lumen always extends itself towards the more determinate things, it is inserted into them, thus giving them being. ${ }^{109}$ The different, specific colors, as well as the different, specific forms, are all lumen. Lux is thus present throughout the material and intelligible worlds through its image and messenger-lumen.

\section{Conclusions}

In this paper, I proposed that the central paradox of the Plotinian metaphysics - that of unity in multiplicity, in which a unity is present within and throughout the plurality of beings while remaining at the same time an undivided, separate whole - can be resolved by the doctrine of two energeiai. According to this doctrine, for each and every entity in the universe, and at every level of being, a differentiation can be made between, on the one hand, the thing in itself, that is, its inner true substance and selfhood, and, on the other hand, an outer spread of representations or images. Further, I pointed out how the relations between these inner and outer activities are elucidated through the relations between a source of light and its external manifestation in the visible splendour.

Plotinus weaves a fabric of identity and difference, continuity and dependence between the two lights. The ability to insist on the source's presence through its images depends on this delicate interplay. The central function of light in accounting for this paradox led Plotinus to speak of it as twofold. The general principle of two energeiai, which when applied to snow produces the couple 'snow-cold', and when applied to perfume produces the pair 'perfume-smell', also produces the pair 'light-light' when applied to light. This double naming underlies similarity between the members of the pair. They are of the same

\footnotetext{
104 The question of the unity of the agent intellect had been the center of a hot debate in the discussed period, following the claim of Averroes (1126-1198) that it is one and the same for all people. Albertus, as many other Christian thinkers, abhorred that assertion and took pains to show, that along with its universality, the agent intellect was also individuated. He wrote the De unitate intellectu especially for that purpose.

105 De intellectu, lib. 2, tr. 1, cap. 3; Albertus Magnus (1800-1899), p. 506.

106 Ibid., p. 507.

107 Albertus, De causis et processu universitatis 2. 1.1 [61:25]. Quoted in Latin by Bonin (2001), p. 105 n. 34.

108 De intellectu, lib. 2, tr. 1, cap. 11; Albertus Magnus (1800-1899), p. 519.

109 Ibid.
} 
kind, whereas for snow and cold, fire and heat, root and tree, the disparity is obvious, and similarity minor. Such pairs cannot be considered one.

Again I stress that these two lights are not the intelligible and corporeal lights, and therefore do not stand for the disparity between the intelligible and the corporeal worlds. Rather, they represent the singular and universal versus the plural and particular. The relations between them are depicted by Plotinus through the characteristics of a source and its copy, an ontological precedent and its antecedent which is similar and dependent on it, a cause and its effect, something that is visible and its invisible principle.

All these features can be discerned to exist within the medieval division of light into lux and lumen. The medieval emphasis upon the distinct existence of these two lights, as manifested in giving them two names, can be considered both as a continuation and an expansion of the Plotinian tradition. The medieval thinkers were not satisfied with applying this distinction to optical descriptions only, and elaborated it far beyond the original use, extending it to new domains. This evolution is exemplified in Albertus's account of the agent intellect as $l u x$, and of the specific forms residing in the possible intellect as lumen.

To be sure, further work is required in order to substantiate this scheme, and to establish the linkage within a historical framework. Nevertheless, I believe that the similarity presented here between Plotinus's and the medieval split of light, along with their comparable functioning as explicative solutions to the problem of unity in multiplicity, cannot be overlooked.

\section{Acknowledgements}

I am grateful to Giora Hon for his comments on this paper, and for encouraging its writing. I wish to thank Bernard R. Goldstein as well, for his advice concerning the translation of the Arabic terms for light.

\section{References}

Adamson, P. (2002). The Arabic Plotinus: A philosophical study of the theology of Aristotle. London: Duckworth. Akdogan, C. (1978). Optics in Albert the Great's De sensu et sensato: An edition, English translation, and analysis. Ph.D. thesis, University of Wisconsin.

Albertus Magnus. (1800-1899). De intellectu et intelligibili. In idem, Opera omnia (A. Borgnet, Ed.) (38 vols.) (Vol. IX, pp. 477-525). Paris: Vives.

Albertus Magnus. (1968). De anima (C. Stroick, Ed.). Alberti Magni Opera omnia, Vol. VII, pars I. Munster: Aschendorff.

Albertus Magnus. (1972). Super Dionysium De divinis nominibus. In idem, Alberti Magni opera omnia, Vol. XXXVII, 1. (P. Simon, Ed.) Munster: Aschendorff.

Armstrong, A.H. (1937). 'Emanation' in Plotinus. Mind, XLVI, 61-66.

Armstrong, A. H. (1967). The architecture of the intelligible universe in the philosophy of Plotinus. Amsterdam: A. M. Hakkert.

Bacon, R. (1983). Roger Bacon's philosophy of nature: A critical edition, with English translation, introduction, and notes, of De multiplicatione specierum and De speculis comburentibus. (B. C. Lindberg, Ed.). Oxford: Clarendon press.

Beierwaltes, W. (1961). Plotins Metaphysik des Lichtes. Zeitschrift fur philosophische Forschung, 15, $334-362$.

Bonin, Th. (2001). Creation as emanation: The origin of diversity in Albert the Great's On the causes and procession of the universe. Indiana: University of Notre Dame.

Bradshaw, D. (2004). Aristotle East and West: Metaphysics and the division of Christendom. Cambridge: Cambridge University Press. 
Brehier, E. (1962). The philosophy of Plotinus (J. Thomas, Trans.). Chicago: University of Chicago Press. (First published 1958)

Bussanich, J. (1996). Plotinus's metaphysics of the one. In L. P. Gerson (Ed.), The Cambridge companion to Plotinus (pp. 38-65). Cambridge: Cambridge University Press.

Corrigan, K. (1993). Light and metaphor in Plotinus and St. Thomas Aquinas. The Thomist, 57, 187-199.

Dionysius the Areopagite. (1951). Dionysius the Areopagite on the divine names and the mystical theology (C. E. Rolt, Trans.). London: Society for Promoting Christian Knowledge. (First published 1920)

Emilsson, E. K. (1988). Plotinus on sense-perception: A philosophical study. Cambridge: Cambridge University Press.

Ferwerda, R. (1965). La signification des images et des métaphores dans la pensée de Plotin. Groningen: J. B. Wolters.

Fielder, J. H. (1976). Chorismos and emanation in the philosophy of Plotinus. In R. B. Harris (Ed.), The significance of Neoplatonism (pp. 101-120). Norfolk: International Society for Neoplatonic Studies.

Gerson, L. P. (1993). Plotinus's metaphysics: Emanation or creation? Review of Metaphysics, 46, 559-574.

Gerson, L. P. (1997). The study of Plotinus today. American Catholic Philosophical Quarterly, 71, 293-300.

Gilson, S. A. (2000). Medieval optics and theories of light in the works of Dante. Lewiston, Queenston, \& Lampeter: Edwin Mellen Press.

Grant, E. (1994). Planets, stars and orbs: The medieval cosmos 1200-1687. Cambridge: Cambridge University Press.

Grosseteste, R. (1912). De motu corporali et luce. In idem, Die philosophischen Werke des Robert Grosseteste, Bischofs von Lincoln (L. Baur, Ed.) (pp. 90-92). Munster: Aschendorff.

Grosseteste, R. (1974a). De operatione solis. In J. J. McEvoy, The sun as res and signum: Grosseteste's Commentary on Ecclesiasticus ch. 43, vv. 1-5. Recherches de Théologie Ancienne et Médiévale, 41, 38-91.

Grosseteste, R. (1974b). On the rainbow (D. C. Lindberg, Trans.). In E. Grant (Ed.), A source book in medieval science (pp. 388-391). Cambridge, MA: Harvard University Press.

Grosseteste, R. (1996a). On light (C. C. Riedl, Trans.). In A. B. Schoedinger (Ed.), Readings in medieval philosophy (pp. 764-770). New York \& Oxford: Oxford University Press. (First published 1942)

Grosseteste, R. (1996b). On the six days of creation: A translation of the Hexaëmeron (C. F. J. Martin, Trans.). Oxford: Oxford University Press.

Gurtler, G. M. (1992). Plotinus and the Platonic Parmenides. International Philosophical Quarterly, 32, 443-457.

Hadley, D. (1997). Plotinus's defense of the sensible: The metaphysics of image and dance in Ennead II. 9 (33). American Catholic Philosophical Quartely, 71, 453-468.

Hager, P. F. (1993). Infinity and simplicity of God in Plotinus, Proclus and Pseudo-Dionysius. Journal of Neoplatonic Studies, 2(1), 45-69.

Hasse, D. N. (2000). Avicenna's De anima in the Latin West: The formation of a peripatetic philosophy of the soul 1160-1300. London: Warburg Institute.

Jay, M. (1993). Downcast eyes: The denigration of vision in twentieth-century French thought. Berkeley \& Los Angeles: University of California Press.

Lindberg, D. C. (1986). The genesis of Kepler's theory of light: Light metaphysics from Plotinus to Kepler. Osiris (2nd series), 2, 5-42.

McEvoy, J. (1982). The philosophy of Robert Grosseteste. Oxford: Clarendon Press.

Plotinus (1959). Plotini opera, Vol. 2 (P. Henry \& H. R. Schwyzer, Eds). Paris: Desclé de Brouwer.

Plotinus. (1966-1988). Plotinus: With an English translation (A. H. Armstrong, Trans.) (7 vols.). Cambridge, MA: Harvard University Press.

Plotinus. (1991). The Enneads (S. MacKenna, Trans.; abridged with an introduction and notes by J. Dillon). London: Penguin. (First Published 1917-1930)

Rappe, S. (1995). Metaphor in Plotinus' Enneads V 8.9. Ancient Philosophy, 15, 155-172.

Ricoeur, P. (1977). The rule of metaphor: Multi-disciplinary studies of the creation and meaning in language (R. Czerny, Trans.). Toronto: University of Toronto Press.

Rist, J. M. (1967). Plotinus: The road to reality. Cambridge: Cambridge University Press.

Roeser, T. P. (1945). Emanation and creation. New Scholasticism, 19, 85-116.

Ronchi, V. (1970). The nature of light: An historical survey (V. Barocas, Trans.). Cambridge, MA: Harvard University Press.

Sabra, A. I. (1989). The Optics of Ibn Al-Haytham: Translated with introduction and commentary. London: Warburg Institute, University of London. 
Schroeder, F. M. (1992). Form and transformation: A study in the philosophy of Plotinus. Montreal \& Kingston: McGill-Queen's University Press.

Schroeder, F. M. (1996). Plotinus and language. In L. P. Gerson (Ed.), The Cambridge companion to Plotinus (pp. 336-355). Cambridge: Cambridge University Press.

Simson, O. von. (1962). The gothic cathedral: Origins of gothic architecture and the medieval concept of order. Princeton: Princeton University Press.

Smith, A. M. (2000). Getting the big picture in perspectivist optics. In M. H. Shank (Ed.), The scientific enterprise in antiquity and the Middle Ages (pp. 315-336). Chicago \& London: University of Chicago Press. (First published in Isis, 72, 1981, 568-589)

Spruit, L. (1994). Species intelligibilis from perception to knowledge. Vol. 1 Classical roots and medieval discussions. Leiden: E. J. Brill.

Zajonc, A. (1993). Catching the light: The entwined history of light and mind. Oxford: Oxford University Press.

Zimmermann, F. W. (1986). The origin of the so-called Theology of Aristotle. In J. Kraye, W. F. Ryan, \& C. B. Schmitt (Eds.), Pseudo-Aristotle in the Middle Ages: The Theology and other texts (pp. 110-240). London: Warburg Institute. 